\title{
SERTIFIKASI DAN LABELISASI HALAL PADA MAKANAN DALAM PERSPEKTIF HUKUM ISLAM (PERSPEKTIF AYAT AHKAM)
}

\author{
Muhammad Syarif Hidayatullah \\ Program Doktor Ilmu Syariah Pascasarjana UIN Antasari Banjarmasin \\ Email: syarif.muhammad849@gmail.com
}

\begin{abstract}
Halal certification and labeling is an update in the food sector and public consumption. Halal certification and labeling on food in circulation, especially instant foods, is something that did not exist in the past. but now its existence has become something that is considered urgent. This paper is a conceptual research related to the study of halal certification and labeling on food in the perspective of Islamic law through the study of legal verses in al-Qur'an. The results of the study show that halal certification and labeling on food by returning to the basic Islamic legal maxim of food "Basically everything (muamalah) is permissible, until there is proposition against it." The verses of the law concerning food contain the command to eat halal and good food, so halal certification and labeling on food is so urgent today as an effort to fulfill these command by creating confidence and certainty in the halalness of a food as well as a form of carefull that will prevent eating haram food.
\end{abstract}

Keywords: Halal Certification, Halal Label, Halal Food

\begin{abstract}
Abstrak
Sertifikasi dan labelisasi halal merupakan bentuk pembaharuan dalam sektor makanan dan konsumsi publik. Sertifikasi dan labelisasi halal pada makanan yang beredar terutama makanan yang sifatnya instan merupakan suatu hal yang sebenarnya tidak ada dimasa lampau, namun saat ini keberadaannya menjadi sesuatu yang dianggap penting. Tulisan ini merupakan penelitian konseptual terkait kajian sertifikasi dan labelisasi halal pada makanan dalam perspektif hukum Islam melalui studi ayat ahkam. Hasil kajian menunjukkan bahwa Sertifikasi dan labelisasi halal pada makanan sebenarnya dapat kita pandang dengan kembali pada kaidah dasar dalam hal makanan yakni "hukum asal segala sesuatu adalah boleh, sampai ada dalil yang melarangnya". Ayat-ayat ahkam tentang makanan memerintahkan untuk memakan makanan yang halal lagi baik, maka sertifikasi dan labelisasi halal pada makanan begitu urgen di masa sekarang sebagai upaya memenuhi perintah tersebut dengan memunculkan keyakinan dan kepastian pada kehalalan suatu makanan serta bentuk kehati-hatian yang akan menghindarkan dari mengonsumsi makanan yang haram.
\end{abstract}

Kata Kunci: Sertifikasi Halal, Label Halal, Makanan Halal 


\section{PENDAHULUAN}

Salah satu yang menjadi kebutuhan pokok dan penting bagi manusia adalah makanan. Kemudian dalam persoalan makanan yang di konsumsi, ada pertimbangan yang mendasari keputusan makanan yang dipilih. Terkadang dalam memilih makanan, cita rasa menjadi faktor utama yang mendorong perilaku konsumsi ini, lalu disisi lain bisa jadi kurang mempedulikan aspek kehalalannya. Konsumen Muslim berpedoman dengan syariat Islam semestinya begitu memperhatikan aspek kehalalan produk dan berharap setiap produk yang dikonsumsi memenuhi kriteria kehalalan sesuai syariat Islam. Bahwasanya pada aspek kehalalan ini mengandung nilai-nilai spiritual bagi diri seseorang, karena itu syariat Islam telah menetapkan rambu-rambu atau ketentuan terkait halal dan haram pada kajian masalah makanan.

Indonesia adalah negara dengan penduduk penduduk Muslim terbesar dunia. Berdasarkan data Global Religious Futures ("Countries by Religion | Religion Information | GRF," t.t.), jumlah penduduk Indonesia pada 2010 yang beragama Islam (muslim) sebanyak 209,12 juta jiwa atau setara $87,17 \%$ dari total penduduk yang mencapai 239,89 juta jiwa. Kemudian menurut data yang dilansir oleh The Pew Forum on Religion $\mathcal{E}$ Public Life tahun 2012 ("Religion \& Public Life - Pew Research Center," t.t.), penganut agama Islam di Indonesia sebesar 209,1 juta jiwa atau 87,2 persen dari total penduduk, persentase ini selaras dengan data dari Portal Informasi Indonesia yakni 87,2 persen (“Indonesia.go.id," t.t.).

Perkembangan zaman yang terjadi ikut mempengaruhi sektor makanan dan konsumsi publik. Dalam persoalan kehalalan makanan, maka telah hadir di tengah masyarakat makanan-makanan yang berlabel halal. Labelisasi halal dan sertifikasinya adalah sesuatu yang sebenarnya tidak ada dimasa lampau, namun saat ini menjadi hal yang dianggap urgen dalam membangun keyakinan, kepercayaan dan kepastian material makanan yang dikonsumsi, terutama bagi seorang muslim, sebab Islam juga mengatur persoalan makanan dengan adanya aturan makanan halal dan haram.

Ada beberapa kajian terdahulu terkait tentang sertifikasi dan labelisasi halal pada makanan seperti tulisan Khabib Solihin dengan judul Analisis Kebijakan Sertifikasi Produk Halal Dalam Perspektif Perlindungan Kemaslahatan Umat. Kemudian kajian lainnya oleh Syafrida dengan judul Sertifikat Halal Pada Produk Makanan Dan Minuman Memberi Perlindungan Dan Kepastian Hukum Hak-Hak Konsumen Muslim. Adapula penelitian oleh Tutik Nurul Jannah yang berjudul Upaya Perlindungan Konsumen Muslim Dan Non-Muslim Melalui Sertifikasi Halal Dan Transparansi Komposisi Produk Makanan. Dibandingkan dengan tulisan-tulisan yang telah disebutkan sebelumnya, kajian yang akan dilakukan penulis memiliki arah kajian yang berbeda secara substansial. Eksistensi sertifikasi dan labelisasi halal 
pada produk makanan serta urgensinya di zaman sekarang dalam tulisan ini akan dibahas melalui kajian ayat ahkam untuk lebih dalam menemukan harmonisasi dan sinkronisasi kebutuhan sertifikat dan label halal dalam realitas sosial dengan ayat suci al-Qur'an sebagai landasan hukum utama dalam Islam.

\section{METODE PENELITIAN}

Kajian dalam tulisan ini menggunakan metode penelitian hukum normatif dengan pendekatan konseptual, sebab yang dikaji dalam tulisan ini adalah konsep sertifikasi dan labelisasi halal yang ditinjau secara yuridis normatif hukum Islam dalam perspektif ayat ahkam. Analisis yuridis beranjak dari ayat-ayat ahkam terkait dengan aspek kehalalan pada makanan.

\section{PEMBAHASAN}

\section{Makanan Halal}

Secara bahasa kata halal berarti terbuka. Sedangkan secara istilah, menurut al-Jurjani berarti setiap sesuatu yang tidak dikenakan sanksi penggunaannya atau sesuatu perbuatan yang dibebaskan syariat untuk dilakukan (al Jurjânî, 1405: 124) Kemudian dalam penjelasan Imam Syaukani dinyatakan sebagai halal karena telah terurainya simpul tali atau ikatan larangan yang mencegah.(al Syaukânî, 2007: 216) Lalu dalam ensiklopedi hukum Islam definisi halal adalah segala sesuatu yang menyebabkan seseorang tidak dihukum jika menggunakannya, atau sesuatu yang boleh dikerjakan menurut syara'(Dahlan, 1996: 505-506).

Pada dasarnya semua makanan yang ada di dunia ini halal untuk dimakan, kecuali terdapat dalil yang melarang baik itu dari al- Qur'an atau hadits. Sesuai dengan kaidah fikih:

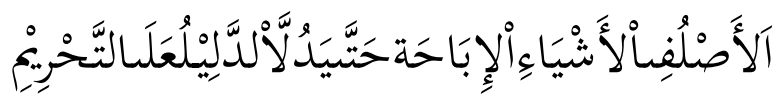

Artinya: "Hukum asal segala sesuatu adalah boleh sampai ada dalil yang melarangnya (memakruhkannya atau mengharamkannya)."

Maksud dari kaidah ini adalah bahwa hukum asal segala sesuatu yang diciptakan Allah SWT adalah halal dan mubah, kecuali terdapat dalil nash yang menunjukkan keharamannya. Dengan kata lain jika tidak terdapat dalil nash atau tidak tegas penunjukan keharamannya, maka sesuatu itu tetaplah pada hukum asalnya yaitu mubah. Sandaran dari kaidah tersebut yaitu QS. al-Baqarah (2): 29,

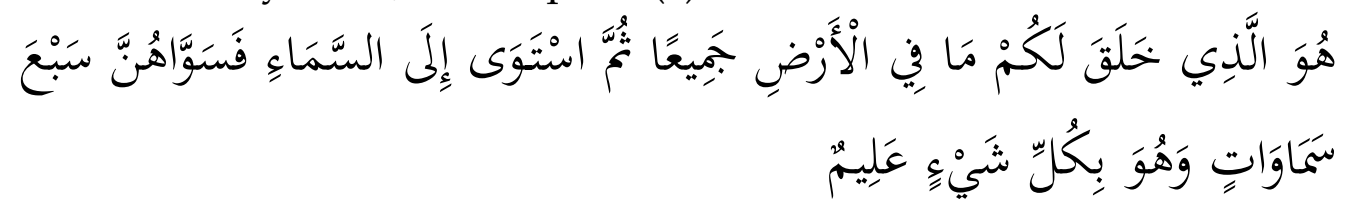


Artinya : "Dia-lah Allah, yang menjadikan segala yang ada di bumi untuk kamu dan Dia berkehendak (menciptakan) langit, lalu dijadikan-Nya tujuh langit. dan Dia Maha mengetahui segala sesuatu".

Ayat tersebut menjelaskan bahwa segala sesuatu yang telah diciptakan Allah di muka bumi ini adalah nikmat darinya dan Allah tidak mengharamkan sesuatu kecuali hanya beberapa bagian saja dan pasti ada hikmah di balik itu yang pada hakikatnya adalah sebuah kemaslahatan pula bagi umat manusia sebab kebaikan dan manfaat kembali kepada manusia itu sendiri.

\section{Kriteria Makanan Halal}

Kriteria makan halal dalam syariat Islam seperti (Girindra, 1998: 124-125): (1) tidak mengandung babi dan bahan berasal dari babi; (2) tidak memabukkan atau bukan khamr maupun produk turunannya; (3) bahan yang berasal dari hewan harus berasal dari hewan yang halal serta disembelih sesuai syariat Islam; (4) tidak termasuk dalam kategori najis seperti bangkai, darah, kotoran dan lain-lain; dan (5) semua tempat penyimpanan, penjualan, pengolahan, pengelolaan dan alat transportasi untuk produk halal tidak boleh digunakan untuk babi atau barang tidak halal. Jika pernah digunakan untuk babi atau tidak halal lainnya dan kemudian akan digunakan untuk produk halal, maka terlebih dahulu harus dibersihkan sesuai dengan cara yang diatur menurut syari' at Islam. Penggunaan fasilitas produksi untuk produk halal dan tidak halal secara bergantian tidak diperbolehkan.

Kehalalan suatu makanan haruslah komprehensif tidak hanya dipandang pada satu faktor saja, haruslah substansi integratif dari berbagai faktor dan sektor. Syarat-syarat dalam kriteria kehalalan harus mencakup halal pada zatnya, cara memperolehnya, cara memprosesnya, kemudian dalam penyimpanannya, pengangkutannya dan penyajiannya (Girindra, 1998: 17).

Jenis-jenis makanan yang halal berdasarkan nash al-Quran maupun hadits seperti yang disampaikan Suryana yakni (Suryana, 2009: 4): (1) semua makanan yang baik, tidak kotor dan menjijikkan; (2) semua makanan yang tidak diharamkan oleh Allah dan Rasul-Nya; (3) semua makanan yang tidak memberi mudharat, tidak membahayakan kesehatan jasmani dan tidak merusak akal, moral dan akidah; dan (4) hewan yang hidup di dalam air, baik air laut maupun air tawar.

\section{Sertifikasi dan Labelisasi Halal}

Sertifikasi halal dan labelisasi halal merupakan dua kegiatan yang berbeda tetapi mempunyai keterkaitan satu sama lain. Hasil dari kegiatan sertifikasi halal adalah diterbitkannya sertifikat halal, apabila produk 
yang dimaksudkan telah memenuhi ketentuan sebagai produk halal. Keberadaan sertifikasi sebenarnya tujuannya adalah sebagai pengakuan secara legal formal bahwa produk yang dikeluarkan telah memenuhi ketentuan halal, sehingga dapat menenteramkan batin konsumen dalam mengkonsumsinya. Sedangkan labelisasi halal adalah pencantuman tulisan atau pernyataan halal pada kemasan produk untuk menunjukkan bahwa produk yang dimaksud berstatus sebagai produk halal (Hasan, 2014: 231).

Kementerian Agama menandatangani nota kesepahaman tentang penyelenggaraan layanan sertifikasi halal di kantor Wakil Presiden, Jakarta, Rabu 16 Oktober 2019. Hal ini dilakukan jelang pemberlakuan Badan Penyelenggaraan Jaminan Produk Halal (BPJPH) pada 17 Oktober 2019. Nota kesepahaman dilakukan bersama Majelis Ulama Indonesia, Badan Pengawas Obat dan Makanan, Kementerian Kesehatan, dan beberapa kementerian/lembaga terkait lainnya. Dengan kata lain, penerbitan sertifikasi halal kini berada di bawah Kementerian Agama sehingga sertifikasi halal tidak diterbitkan lagi oleh Majelis Ulama Indonesia seperti tahun-tahun sebelumnya. Kewajiban bagi produk yang bersertifikat halal akan dilakukan secara bertahap. Untuk makanan dan minuman dimulai pada 17 Oktober 2019 sampai 17 Oktober 2024. Sedangkan untuk produk di luar makanan dan minuman, maka kewajiban sertifikasi halalnya dimulai pada 17 Oktober 2021 dengan jangka waktu masing-masing sesuai dengan karakteristik produk (VIVA, 2019).

\section{Aspek Kehalalan Makanan dalam Kajian Ayat Ahkam}

Berkembangnya zaman dan pesatnya kemajuan tekhnologi, para produsen memproduksi produk makanan dalam bentuk kemasan yang tidak menutup kemungkinan mencampurkan bahan olahan pangan dengan bahan yang dilarang agama. Sehingga kehalalan produk olahan tersebut diragukan. Bisa saja terjadi, bahan-bahan yang haram dimanfaatkan sebagai bahan baku, bahan tambahan atau bahan penolong pada berbagai produk olahan, karena dianggap lebih ekonomis.

Persepsi masyarakat tentang keharaman sebuah produk masih sangat sederhana sebelum teknologi pengolahan pangan pesat berkembang seperti sekarang. Masalah halal haramnya makanan atau minuman hanya terkait dengan ada atau tidaknya produk yang mengandung babi atau mengandung alkohol. Jika makanan atau minuman yang bebas dari kedua bahan tersebut, otomatis dianggap halal. Namun kini, teknologi pengolahan pangan telah mengubah persepsi tersebut. Sebab produksi makanan untuk keperluan konsumsi tidak lagi hanya mengandalkan bahan utama saja, tetapi juga memerlukan bahan tambahan. 
Konsumen muslim dalam membeli produk makanan dan minuman atau produk lain ada kecenderungan khawatir dengan status kehalalannya, tetapi dengan melihat komposisi (ingredients) yang tertera pada produk tersebut akan mengetahui adanya bahan haram atau tidak. Jika tidak ada bahan haram atau yang meragukan tertulis di sana, maka dapat memunculkan keyakinan dan persepsi kepastian atas produk tersebut yaitu halal. Masalahnya untuk mengecek komposisi produk itu membutuhkan pengetahuan tentang bahan-bahan tersebut, tetapi dengan pengetahuan inipun belum tentu dapat menjamin kepastian halal seratus persen. Karena produk makanan atau minuman tersebut biasanya diperkaya dengan bahan aditif (bahan tambahan) seperti, flavor (perisa), pewarna makanan, dan zat aditif lainnya. Dan tidak menutup kemungkinan bahan aditif tersebut dapat menjadikan haram suatu produk makanan

Ketentuan makanan yang halal dalam syariat Islam yang bersumber dari nash antara lain:

1. Suci, bukan najis atau yang terkena najis. Allah berfirman dalam QS. al-Baqarah (2): 173,

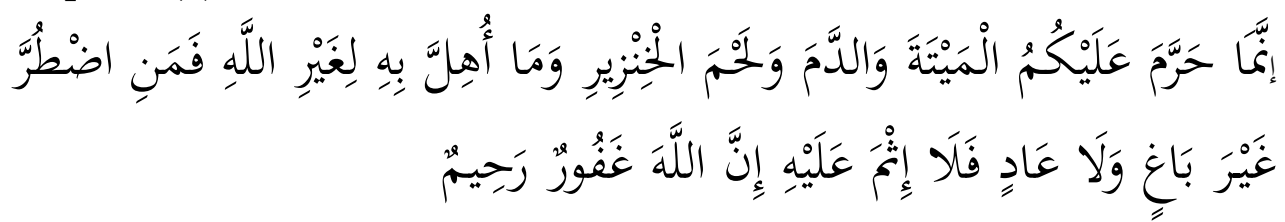

Artinya: "Sesungguhnya Allah hanya mengharamkan bagimu bangkai, darah, daging babi, dan binatang yang (ketika disembelih) disebut (nama) selain Allah. tetapi Barangsiapa dalam Keadaan terpaksa (memakannya) sedang Dia tidak menginginkannya dan tidak (pula) melampaui batas, Maka tidak ada dosa baginya. Sesungguhnya Allah Maha Pengampun lagi Maha Penyayang."

2. Aman, tidak bermudharat baik yang langsung maupun yang tidak langsung. Allah berfirman dalam QS. al-Baqarah (2): 195

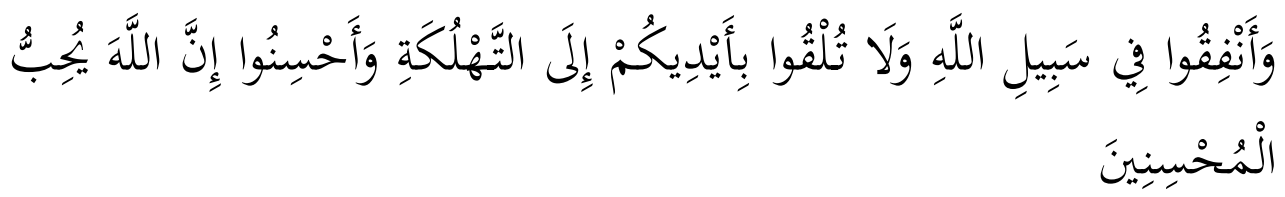

Artinya : "Dan belanjakanlah (harta bendamu) di jalan Allah, dan janganlah kamu menjatuhkan dirimu sendiri ke dalam kebinasaan, dan berbuat baiklah, karena Sesungguhnya Allah menyukai orangorang yang berbuat baik." 
3. Tidak memabukkan. Dalam sebuah hadits dijelaskan (an Naisabûri, t.t.,: 1588):

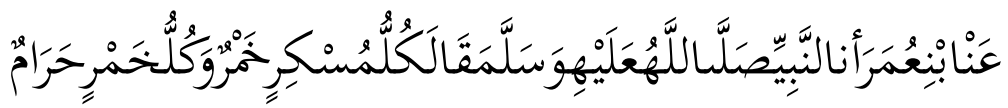

Dari Ibnu Umar RA, bahwasanya Rasulullah SAW telah bersabda, "Setiap yang memabukkanitu adalah khamar (minum keras) dan setiap khamar (minuman keras) itu adalah haram." (HR. Muslim)

4. Disembelih dengan penyembelihan yang sesuai dengan syariat jika makanan itu berupa daging hewan. Allah SWT berfirman dalam QS. al-Maidah (5): 3,

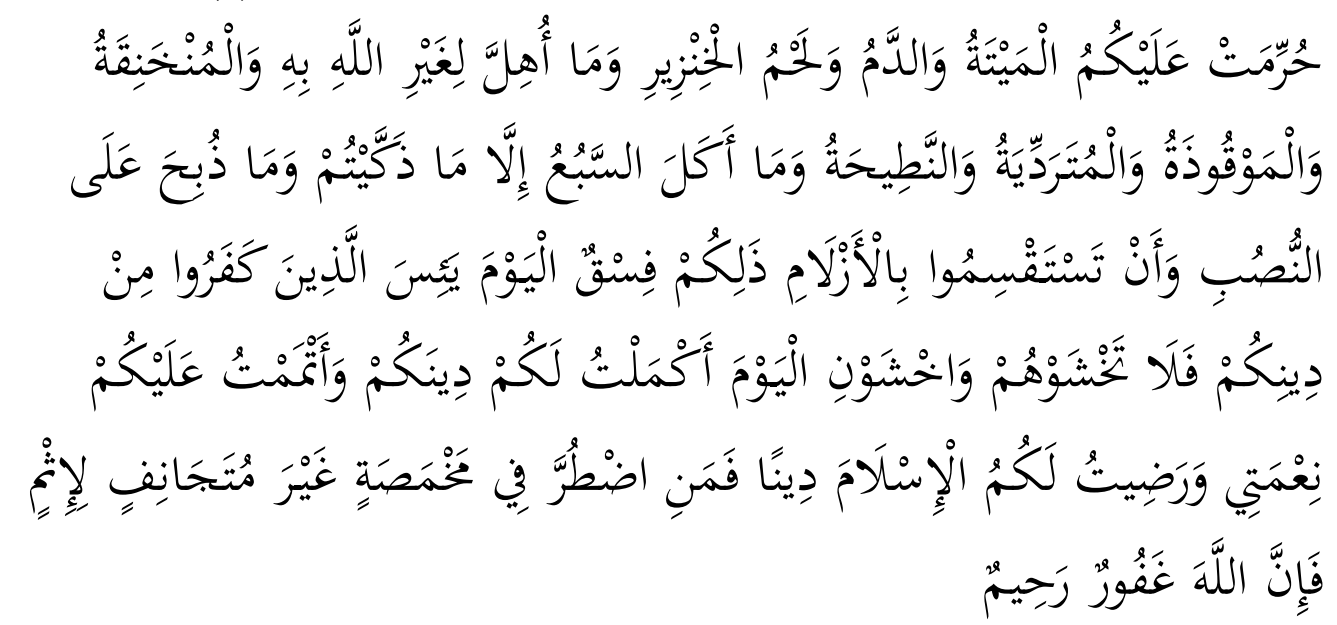

Artinya : 'Diharamkan bagimu (memakan) bangkai, darah, daging babi, (daging hewan) yang disembelih atas nama selain Allah, yang tercekik, yang terpukul, yang jatuh, yang ditanduk, dan diterkam binatang buas, kecuali yang sempat kamu menyembelihnya, dan (diharamkan bagimu) yang disembelih untuk berhala. dan (diharamkan juga) mengundi nasib dengan anak pana, (mengundi nasib dengan anak panah itu) adalah kefasikan. pada hari ini orang-orang kafir telah putus asa untuk (mengalahkan) agamamu, sebab itu janganlah kamu takut kepada mereka dan takutlah kepada-Ku. pada hari ini telah Kusempurnakan untuk kamu agamamu, dan telah Ku-cukupkan kepadamu nikmat-Ku, dan telah Ku-ridhai Islam itu Jadi agama bagimu. Maka barang siapa terpaksa karena kelaparan tanpa sengaja berbuat dosa, Sesungguhnya Allah Maha Pengampun lagi Maha Penyayang." 
5. Hewan Air. Allah SWT berfirman dalam QS. al-Maidah (5): 96:

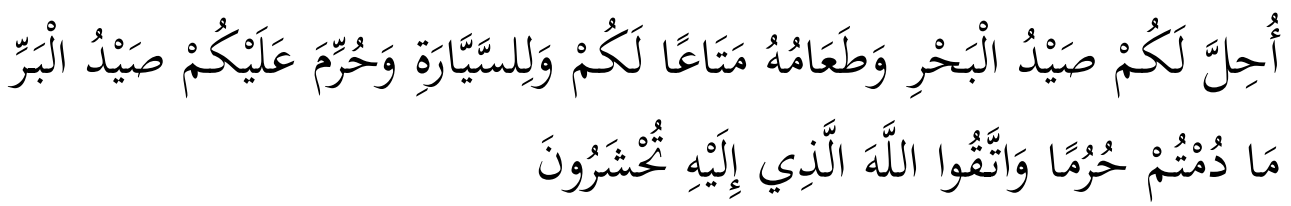

Artinya: "Dihalalkan bagimu binatang buruan laut dan makanan (yang berasal) dari laut sebagai makanan yang lezat bagimu, dan bagi orang-orang yang dalam perjalanan; dan diharamkan atasmu (menangkap) binatang buruan darat, selama kamu dalam ihram. dan bertakwalah kepada Allah yang kepada-Nyalah kamu akan dikumpulkan."

6. Dua Darah dan Dua Bangkai. Hadits Rasulullah SAW(al Qazwînî, t.t.: 1102):

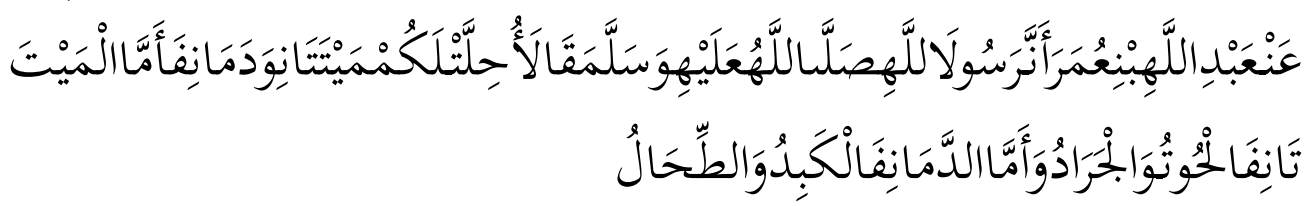

Dari Abdullah bin Umar, Rasulullah Shallallahu 'alaihi wa sallam bersabda," Kami dihalalkan dua bangkai dan darah. Adapun dua bangkai tersebut adalah ikan dan belalang. Sedangkan dua darah tersebut adalah hati dan limpa."(HR. Ibnu Majah)

Pada dasarnya Allah memerintahkan dalam al Quran untuk memakan makanan yang halal lagi baik. Allah SWT berfirman dalam QS. Al-Baqarah: 168-169,

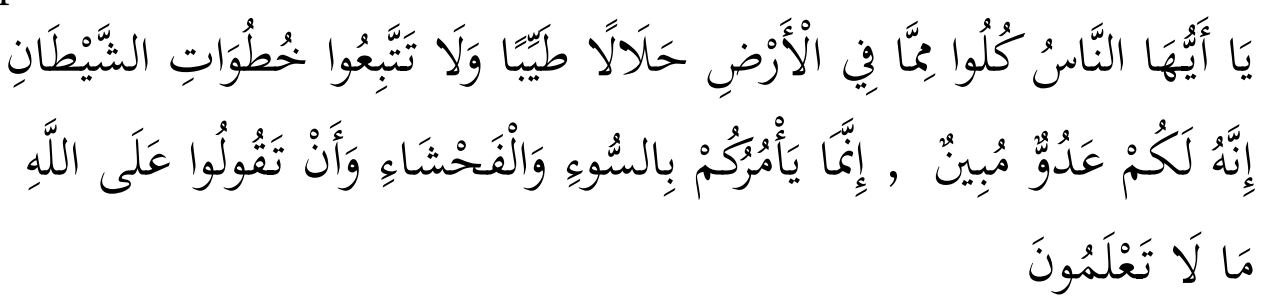

Artinya : "Hai sekalian manusia, makanlah yang halal lagi baik dari apa yang terdapat di bumi, dan janganlah kamu mengikuti langkahlangkah syaitan; karena Sesungouhnya syaitan itu adalah musuh yang nyata bagimu. Sesungguhnya syaitan itu hanya menyuruh kamu berbuat jahat dan keji, dan mengatakan terhadap Allah apa yang tidak kamu ketahui." 
Tafsir ayat di atas dalam berbagai referensi kitab tafsir dapat dilihat pada tabel berikut:

Tabel 2: Tafsir Ayat Ahkam al-Maidah (5): 88

\begin{tabular}{|c|c|}
\hline Kitab Tafsir & Penafsiran \\
\hline Tafsir al-Azhar & $\begin{array}{l}\text { Janganlah memakan asal baik saja, tetapi tidak } \\
\text { halal. Ada pula makanan yang awalnya halal, } \\
\text { kemudian menjadi haram atau sekurang- } \\
\text { kurangnya makruh. Oleh sebab itu maka di } \\
\text { dalam memilih makanan yang halal tetapi baik } \\
\text { dan yang baik tetapi halal ini, selain daripada } \\
\text { yang ditentukan Allah dalam al-Quran } \\
\text { diserahkan pulalah dalam ijtihad kita sendiri } \\
\text { memilih mana yang halal dan baik itu. Itu } \\
\text { sebabnya ujung ayatnya berbunyi, "dan } \\
\text { bertaakwalah kepada Allah dan kepadaNya lah } \\
\text { kamu beriman." Dengan ketentuan tentang halal } \\
\text { dan baik, lalu diserahkan kepada pertimbangan } \\
\text { bathin, yaitu taqwa dan iman, bertambah } \\
\text { pentinglah memilih makanan yang layak di } \\
\text { dunia ini (Hamka, 1983, hlm. 30). }\end{array}$ \\
\hline Tafsir al-Mishbah & $\begin{array}{l}\text { Setelah ayat yang sebelumnya melarang } \\
\text { mengharamkan yang halal, disini ditegaskan } \\
\text { perintah memakan yang halal dengan demikian, } \\
\text { melalui ayat ini dan ayat sebelumnya yang } \\
\text { menghasilkan makna larangan dan perintah } \\
\text { bolehnya memakan segala yang halal. Dengan ini } \\
\text { tercegah pulalah praktik-praktik keberagaman } \\
\text { yang melampaui batas. Dan makanlah yang halal, } \\
\text { yakni yang bukan haram, lagi baik, lezat, bergizi, } \\
\text { dan berdampak positif bagi kesehatan dari yang } \\
\text { Allah telah rezekikan kepada kamu, dan bertakwalah } \\
\text { kepada Allah dalam segala aktivitas kamu yang } \\
\text { kamu terhadapNya adalah mu'minunm yakni } \\
\text { orang-orang yang mantap keimanannya(Shihab, } \\
\text { 2002, hlm. 231). }\end{array}$ \\
\hline Tafsir ath-Thabari & $\begin{array}{l}\text { Abu Ja'far berkata: Allah melarang orang-orang } \\
\text { mukmin untuk mengharamkan makanan yang } \\
\text { baik, yang telah Allah halalkan kepada mereka, } \\
\text { "makanlah kalian wahai orang-orang mukmin, } \\
\text { dari rezeki Allah yang memberikan kalian rezeki } \\
\text { dan menghalalkan kepada kalian yang baik." } \\
\text { Riwayat yang sesuai dengan penjelasan tersebut }\end{array}$ \\
\hline
\end{tabular}




\begin{tabular}{|l|l|}
\hline adalah “Al Qasim menceritakan kepada kami, ia \\
berkata: Al Husain menceritakan kepada kami, ia \\
berkata: Hajjaj menceritakan kepadaku dari Ibnu \\
Juraij dari Ikrimah tentang ayat "makanlah \\
makanan yang halal lagi baik dari apa yang Allah \\
telah rezekikan kepada mu,"bahwa maksudnya \\
adalah apa yang telah Allah halalkan kepada \\
mereka dari makanan(ath Thabari, 2008, hlm. \\
292-293).
\end{tabular}

Selanjutnya QS. an-Nahl (16): 114

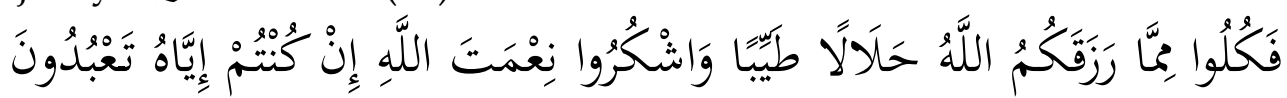

Artinya : "Maka makanlah yang halal lagi baik dari rezki yang telah diberikan Allah kepadamu; dan syukurilah nikmat Allah, jika kamu hanya kepada-Nya saja menyembah".

Tabel 3: Tafsir Ayat Ahkam an-Nahl (16): 14

\begin{tabular}{|l|l|}
\hline Kitab Tafsir & Penafsiran \\
\hline Shafwatut Tafsir & "Maka makanlah yang halal lagi baik dari rezeki \\
yang telah diberikan Allah kepadamu," makanlah \\
nikmat Allah yang Dia halalkan untuk kalian \\
dalam keadaan halal dan enak, "dan syukurilah \\
nikmat Allah jika kamu hanya kepadaNya saja \\
menyembah," bersyukurlaah kalian kepada \\
Allah atas nikmatNya yang besar jika kalian \\
ikhlas beriman tidak menyembah siapapun \\
selain Dia(ash Shabuni, 2011, hlm. 179). \\
\hline Tafsir Fathul Qadir \\
$\begin{array}{l}\text { Penggunaan huruf fa disini bertujuan untuk } \\
\text { menunjukkan bahwa itu merupakan dampak } \\
\text { dari diitinggalkannya kekufuran. Maknanya } \\
\text { yaitu sesungguhnya setelah kalian beriman dan } \\
\text { meninggalkan kekufuran, makanlah yang halal } \\
\text { lagi baik, yaitu harta rampasan perang, dan } \\
\text { tinggalkanlah yang buruf, yaitu bangkai dan } \\
\text { darah (dan seterusnya yang disebutkan itu). } \\
\text { Adapula yang menyebutkan bahwa huruf fa } \\
\text { pada fakulu (maka makanlah) termasuk cakupan } \\
\text { perintah untuk bersyukur,dan dimasukkan } \\
\text { perintah untuk memakan, karena makan bisa } \\
\text { mengantar kepada kesyukuran(asy Syaukani, } \\
\text { 2011, hlm. 461). }\end{array}$ \\
\hline Tafsir Imam Syafi'i Syafi'i Mengatakan,"menurut satu \\
\hline
\end{tabular}




\begin{tabular}{|c|c|}
\hline & $\begin{array}{l}\text { pendapat berkenaan masalah itu Allah } \\
\text { menurunkan ayat "katakanlah, tiadalah aku } \\
\text { peroleh dalam apa yang diwahyukan kepadaku, } \\
\text { sesuatu yang diharamkan bagi orang yang hendak } \\
\text { memakannya,"sampai firmannya,"atau hewan } \\
\text { yang disembelih atas nama selain Allah." (QS. } \\
\text { Al An'am/6: 145). } \\
\text { Pendapat ini tepat sekali. Maksudnya yaitu } \\
\text { hewan ternak, kecuali bangkai, darah yang } \\
\text { ditumpahkan dari hewan ternak selagi hidup, } \\
\text { atau sembelihan orang kafir. Selain itu } \\
\text { disebutkan pula pengharaman babi. Menurut } \\
\text { pendapat lain disebutkan bahwa kalian tidak } \\
\text { boleh makan kecuali seperti demikian. } \\
\text { Allah berfirman,"Maka makanlah yang halal lagi } \\
\text { baik dari rezki yang telah diberikan Allah kepada } \\
\text { kalian," sampai firmannya,"hewan yang } \\
\text { disembelih dengan menyebut nama selain Allah." } \\
\text { Ayat ini semakna dengan ayat sebelumnya(al } \\
\text { Farran, 2008, hlm. 41). }\end{array}$ \\
\hline $\begin{array}{l}\text { Tafsir Al Quran } \\
\text { Tematik } \\
\text { Kementerian } \\
\text { Agama }\end{array}$ & $\begin{array}{l}\text { Ayat tersebut mensyaratkan bahwa makanan } \\
\text { yang berkualitas dalam pandangan agama } \\
\text { adalah yang halal dan baik. Halal dari aspek } \\
\text { perolehannya dan baik dari aspek zat makanan, } \\
\text { yaitu yang mengandung zat-zat yang memang } \\
\text { dibutuhkan oleh tubuh manusia. Diantara } \\
\text { prinsip makanan yang sehat dan bermanfaat } \\
\text { adalah food combining yaitu pola makanan yang } \\
\text { didasarkan pada prinsip-prinsip(Lajnah } \\
\text { Pentashihan Mushaf Al Quran, 2014, hlm. 258- } \\
\text { 259): } \\
\text { 1. Pilih makanan yang bebas dari inteksida } \\
\text { 2. Makanan yang cukup jumlahnya } \\
\text { 3. Makan makanan yang lengkap } \\
\text { 4. Pastikan semua makanan yang } \\
\text { dimasukkan ke mulut kita adalah } \\
\text { makanan yang mengandung zat yang } \\
\text { dibutuhkan tubuh kita } \\
\text { 5. Pastikan semua makanan diolah dengan } \\
\text { benar. }\end{array}$ \\
\hline
\end{tabular}




\section{Analisis Sertifikasi dan Labelisasi Halal pada Makanan dalam Perspektif Ayat Ahkam}

Pada dasarya perintah label halal pada makanan jika dilihat dari berbagai tafsir yang telah disampaikan sebelumnya, secara eksplisit memang tidak ada. Di masa lampau pula makanan dengan label halal juga tidak ada. Namun saat kita melihat situasi dan kondisi yang terjadi saat ini, pembaharuan sektor pangan dengan sertifikasi dan labelisasi halal menjadi sangat penting.

Setiap konsumem memiliki hak untuk memperoleh informasi yang jelas dan benar terhadap apa yang akan diterimanya dari produsen. Setiap produk yang ditawarkan kepada konsumen termasuk makanan dan minumanharuslah disertakan informasi yang jelas, benar, dan jujur untuk menghindari kekeliruan persepsi. Hal inipun telah memiliki landasan yuridis melalui Undang-Undang Nomor 8 Tahun 1999 tentang Perlindungan Konsumen yang keberadaan undang-undang ini memberikan perlindungan hukum atas kepentingan setiap individu di masyarakat (Latif, 2020: 21-22).

Pencantuman logo halal yang telah tersertifikasi melalui pengujian kehalalan pada produk makanan dan minuman sebenarnya merupakan pemenuhan hak perlindungan konsumen muslim (Janah, 2020: 83). Jadi keberadaannya adalah melindungi konsumen muslim terhadap produk yang tidak halal dengan memberikan kepastian hukum kepada konsumen muslim bahwa produk makanan dan minuman tersebut benar-benar halal sesuai yang disyariatkan oleh Hukum Islam. Konsumen muslim tidak akan ragu-ragu membeli produk makanan dan minuman, karena pada kemasan produk makanan dan minuman tercantum logo halal dan mencegah konsumen muslim terhadap produk yang tidak halal (Syafrida, 2016: 170).

Ketentuan mengenai perlindungan konsumen ini sebenarnya telah tercantum dalam pembukaan Undang-Undang Dasar Republik Indonesia Tahun 1945 Alinea IV yang menyebutkan bahwa negara Indonesia melindungi segenap bangsa Indonesia dan seluruh tumpah darah Indonesia. Oleh karena itu, hadirnya Undang-Undang Jaminan Produk Halal merepresentasikan tanggung jawab negara, khususnya umat Islam untuk memberikan rasa tenang dan aman dalam mengonsumsi/menggunakan produk yang sesuai syariat yakni halal lagi baik (Hasan, 2014: 230).

Apabila suatu produk makanan dan minuman itu tidak halal (haram), berdasarkan Undang-Undang Nomor 33 Tahun 2014 Tentang Jaminan Produk Halal, pelaku usaha berkewajiban untuk memberikan tanda pada produk makanan dan minuman tersebut tidak halal. Tanda dapat dalam bentuk gambar, seperti kalau di Bali di tempat makanan dan minuman yang mengandung unsur babi terdapat gambar babi. Ini berarti 
pelaku usahanya jujur, karenan dalam undang-undang perlindungan konsumen pelaku usaha berkewajiban untuk memberikan informasi mengenai komposisi pada produk makanan dan minuman. Selayaknya pelaku usaha di Indonesia yang memperdagangkan produk makanan dan minuman memberikan informasi yang jelas, jujur mengenai komposisi, kehalalan produk makanan dan minuman yang diperdagangkan untuk melindungi hak-hak konsumen muslim terhadap produk yang tidak halal (Syafrida, 2016: 170).

Pada dasarnya kebijakan sertifikasi produk halal sebagaimana ditetapkan dalam regulasi terkait yakni Undang-Undang Republik Indonesia Nomor 33 Tahun 2014 tentang Jaminan Produk Halal dan Peraturan Pemerintah RI No. 31 Tahun 2019 tentang Pelaksanaan Undang-Undang Republik Indonesia Nomor 33 Tahun 2014 tentang Jaminan Produk Halal bertujuan untuk memberikan keamanan, kenyamanan, keselamatan, dan kepastian ketersediaan produk halal bagi masyarakat muslim dalam mengonsumsi dan menggunakan serta meningkatkan nilai tambah bagi pelaku usaha untuk memproduksi dan menjual produk halal. Tujaun ini tidak lain berada dalam bingkai kemaslahatan yang selaras dengan pola konsumsi halal lagi baik sesuai syariat Islam (Solihin, 2020: 33).

Akan tetapi masih banyak ditemukan produk makanan dan minuman yang beredar dimasyarakat belum mencantumkan logo halal atau logo halal yang masih diragukan kebenarannya. Produk yang tidak ada logo halalnya sebenarnya belum tentu haram, begitu juga produk yang ada logo halalnya belum tentu juga halal, karena tidak menutupkemungkinan produknya tidak halal kemudian mencantukan label halal buatan sendiri atau bukan label halal yang telah tersertifikasi melalui pengujian kehalalan oleh lembaga kompeten dan berwenang yang pada akhirnya mengeluarkan keabsahan label halal. Dalam hukum Islam yang dikatakan halal tidak hanya zatnya, tapi juga mulai dari proses produksi dari hulu sampai hilir harus terbebas dari zat-zat yang diharamkan oleh syariat Islam. Penyimpanan produk yang halal tidak boleh bercampur-baur dengan produk yang tidak halal, artinya tempat penyimpanan produk halal harus terpisah dengan produk yang tidak halal. Begitu juga alat yang dipakai untuk memproses produk halal tidak boleh dipakai bersama dengan produk yang tidak halal (Syafrida, 2016: 170).

Fungsi sertifikat halal dapat dilihat dari dua perspektif, yakni perspektif konsumen dan produsen (Pelu, 2009: 31-35). Perspektif konsumen, sertifikat halal memiliki fungsi antara lain:

1. Terlindungnya konsumen muslim dari mengonsumsi pangan, obatobatan dan kosmetika yang tidak halal

2. Secara kejiwaan perasaan hati dan abtin konsumen akan tenang 
3. Mempertahankan jiwa dan raga dari keterpurukan akibat produk haram

4. Akan memberikan kepastian dan perlindungan hukum

Perspektif produsen, maka sertifikat halal berfungsi:

1. Sebagai pertanggungjawaban produsen kepada konsumen muslim, mengingat masalah halal merupakan bagian dari prinsip hidup muslim

2. Meningkatkan kepercayaan dan kepuasan konsumen

3. Meningkatkan citra dan daya saing perusahaan

4. Sebagai alat pemasaran serta untuk memperluas area jaringan pemasaran

5. Memberi keuntungan pada produsen dengan meningkatkan daya saing dan omset produksi penjualan.

Melalui penjabaran sebelumnya, baik dari paparan tafsir dan substansi terkait label halal dalam perundang-undangan, maka secara mendasarnya perlu kita kembalikan persoalan makanan ini pada kaidah dasarnya. Kaidah yang berlaku untuk masalah makanan yakni:

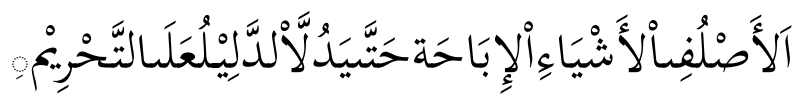

Artinya: "Hukum asal segala sesuatu adalah mubah (boleh), sampai ada dalil yang melarangnya (memakruhkannya atau mengharamkannya)."

Secara sederhana makanan yang halal adalah bukan makanan yang Allah haramkan. Maka dari itu untuk mengetahui makanan tersebut halal atau tidak, perlu diidentifikasi ada tidaknya unsur terlarang atau unsur yang diharamkan dalam makanan tersebut. Lalu untuk saat ini dengan perkembangan zaman yang terjadi maka ikut pula mempengaruhi sektor pangan dengan penyebaran makanan di tengah masyarakat. Merespon hal tersebut ikut mempengaruhi munculnya sertifikasi dan labelisasi halal.

Memperhatikan kepada peredaran makanan saat ini yang telah tergerus perkembangan zaman bahwasanya makanan tidak lagi berasal bahan alami, tetapi mulai bercampurnya pada bahan atau zat kimiawi, makanan tidak lagi hanya sebatas bahan utama, tetapi ada bahan percampuran dan bahan tambahan. Percampuran makanan dari berbagai material dan zat dalam makanan sudah menjadi hal yang lumrah terjadi saat ini. Itulah dimana eksistensi label halal menjadi sangat penting demi perlindungan konsumen muslim agar tidak ada keragu-raguan lagi dalam mengonsumsi suatu makan dan bentuk kehati-hatian tidak mengonsumsi sesuatu yang haram.

Saat kita berbicara ayat ahkam yang dalam kerangka dasar ajaran islam substansinya masuk pembahasan syariah, tidak lepas dari fiqih dan 
ushul fiqih, maka eksistensi pemberlakuan labelisasi halal pada makanan dapat dipandang dalam beberapa pendekatan, yaitu:

1. Maqashid al-Syariah

Muhammad Abu Zahrah menyatakan bahwa tujuan hakiki hukum Islam adalah kemaslahatan. Kemudian senada dengan pernyataan tersebut, Fathi ad-Darayni menyebutkan bahwa hukumhukum tidaklah dibuat untuk hukum itu sendiri melainkan dibuat untuk tujuan kemaslahatan (ad Dâraynî, 1975: 28). Tujuan Allah SWT. mensyariatkan hukumnya adalah untuk memelihara kemaslahatan manusia sekaligus untuk menghindari mafsadat, baik di dunia maupun di akhirat. Tujuan tersebut hendak dicapai melalui taklif yang pelaksanaannya tergantung pada penalaran sumber hukum utama yaitu al-Quran dan Hadits (Djamil, 1997: 125).

Kamaslahatan yang menjadi tujuan syari'at ini dibatasi dalam lima hal, yaitu agama, jiwa, akal, keturunan dan harta. Setiap hal yang mengandung penjagaan atas lima hal tersebut disebut maslahah dan setiap hal yang membuat hilangnya lima hal disebut mafsadah. Maka eksistensi label halal pada makanan merupakan sesuatu yang sebenarnya akan menuju pada kemaslahatan, sebab merupakan manifestasi dari hifzh al-din (memelihara agama), hifzh al-nafs (memelihara jiwa) dan hifzh al-aql (memelihara akal) karena akan menjadi cara untuk mengonsumsi makanan yang halal dan menghindari makanan yang haram sebagaimana yang telah disyariatkan dalam ajaran Islam.

2. Mashlahah Mursalah

Maslahah mursalah terbagi menjadi dua kata, yaitu maslahah dan mursalah. Maslahah secara harfiah berarti manfaat atau terlepas dari padanya kerusakan. Mursalah berarti terlepas atau bebas. Digabungkan menjadi maslahah mursalah secara istilah adalah kemaslahatan yang keberadaanya tidak didukung syara' dan juga tidak ditolak oleh syara' melalui dalil-dalil terperinci. Disebut sebagai suatu maslahah, karena hukum yang ditetapkan berdasarkan maslahah ini, dapat menghindarkan mukallaf dari suatu hal yang mudharat dan juga akan mendatangkan manfaat dan kebaikan bagi mukallaf (Mufid, 2016: 117-118).

3. Sad Adz Dzari'ah

Pada dasarnya Sad adz Dzari'ah merupakan upaya preventif, yakni menutup jalan yang akan menjembatani dan mengarahkan kepada sesuatu yang mafsadah atau yang diharamkan. Maka label halal dalam makanan merupakan upaya preventif agar orang-orang muslim terlindungi dari memakan sesuatu yang haram dan membawa mafsadah. 


\section{Kaidah Fikih}

Kaidah-kaidah fikihsebagai formulasi produk hukum yang dapat dikaitkanpada permasalahan sertifikasi dan labelisasi halal sebagai kaidah mengonstruksi kehadirannya pada peredaran makanan saat ini adalah sebagai berikut (Abdurrahman, 1986: 2; Azhari, 2014: 184; Djazuli, 2006: 137; Fila, 2020: 60; Tamrin, 2010: 181):

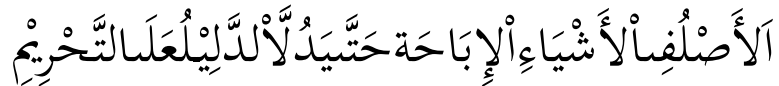

"Hukum asal segala sesuatu (muamalah) adalah mubah sampai ada dalil yang melarangnya."

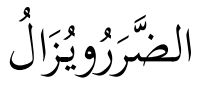

"Kemudharatan itu harus dihilangkan".

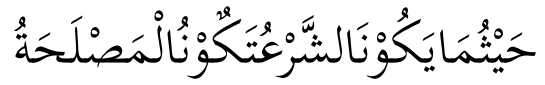

"Apabila hukum syara' dilaksanakan, maka pastilah tercipta kemaslahatan."

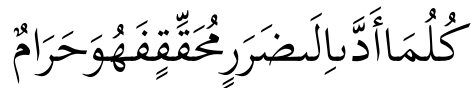

"Segala apa yang menyebabkan terjadinya kemudharatan (bahaya) maka hukumnya haram".

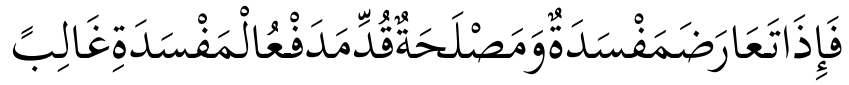

"Maka jika terjadi pertentangan antara menghilangkan mafsadah (kerusakan) dari satupihak dengan mendatangkan kemaslahatan di pihak lain, maka prinsip menghilangkan mafsadah (Kerusahak) harus di dahulukan dari yang kedua".

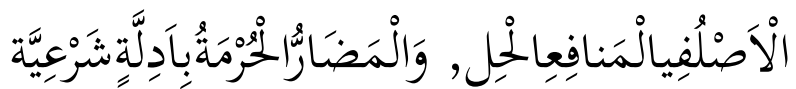

"Pada dasarnya semua yang bermanfaat halal dan yang membahayakan haram dengan petunjuk syariat".

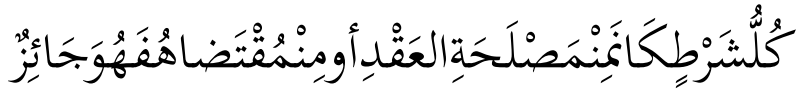

"Setiap syarat untuk kemaslahatan akad atau diperlukan oleh akad tersebut, maka syarat tersebut dibolehkan". 


\section{SIMPULAN}

Hasil kajian menunjukkan bahwa hadirnya sertifikasi dan labelisasi halal pada makanan terutama makanan instan serta makanan yang diimpor dari luar negeri di era sekarang pada dasarnya untuk melindungi konsumen yakni hak-hak konsumen muslim terhadap produk yang tidak halal. Jadi memberikan kepastian hukum kepada konsumen muslim bahwa produk makanan dan minuman tersebut benar-benar halal sesuai yang disyariatkan dalam Hukum Islam. Dengan begitu konsumen muslim tidak akan ragu-ragu membeli produk makanan. Selain itu pula memiliki peran penting baik dari sudut pandang produsen maupun konsumen.

Pada masa lampau memang tidak ada sertifikasi dan labelisasi halal, tapi kehadirannya dapat kita pandang dengan kembali pada kaidah dasar dalam hal makanan yakni hukum asal segala sesuatu (muamalah) adalah boleh, sampai ada dalil yang melarangnya. Maka pada ayat-ayat ahkam tentang makanan tidak ada larangan terhadap pencantuman label halal. Selain itu ayat-ayat ahkam tentang makanan memerintahkan untuk memakan makanan yang halal lagi baik, maka sertifikasi dan labelisasi halal pada makanan begitu urgen di masa sekarang. Dirasakan saat ini memang hadirnya sertifikasi dan labelisasi halal begitu urgen sebagai upaya untuk mewujudkan keyakinan dan kepastian kehalalan suatu makanan serta bentuk kehati-hatian yang akan menghindarkan dari memakan sesuatu yang haram. Selain itu eksistensi dan urgensi label halal pada makanan yang didasarkan pada sertifikasi kehalalan yang dikeluarkan oleh lembaga yang kompeten dan berwenang dalam pengujian kehalalan dapat dipandang melalui pendekatan maqashid alsyariah, mashlahah mursalah, sad adz dzari'ah dan qawa'id fighiyyah.

\section{DAFTAR PUSTAKA}

\section{Buku-buku}

Abdurrahman, J. Lima Kaidah Pokok dalam Fikih Mazdhab Syafi'i (A. Syukur, Penerj.). Surabaya: Bina Ilmu, 1986.

ad Dâraynî, F. Al-Minhâj al-Ushûliyyah fî Ijtihâd bî ar-Ra'yi fî at-Tasyrî́. Damaskus: Dâr al-Kutub al-Hadîts, 1975.

al Farran, A. M. Tafsir Imam Syafi'i (Vol. 3; I. G. Masykur, Penerj.). Jakarta: Penerbit Almahira, 2008.

al Qazwînî, A. A. M. B. Y. bin M. Sunan Ibnu Mâjah (Vol. 2). Kairo: Dâr alIhya' al-Kutub al-'Arabiyah, t.t.

al Syaukânî, M. bin 'Ali bin M. bin 'Abdullah. Fath al-Qâdir. Beirut: Dâr alMa'rifah, 2007. 
an Naisabûri, M. bin al H. A. al H. al Q. Shahîh Muslim (Vol. 3). Beirut: Dâr Ihyâ at-Turats, t.t.

ash Shabuni, M. A. Shafwatut Tafsir (Vol. 3). Jakarta: Pustaka Al Kautsar, 2011.

asy Syaukani, I. Tafsir Fathul Qadir (Vol. 6). Jakarta: Pustaka Azzam, 2011.

ath Thabari, A. J. M. bin J. Tafsir ath-Thabari (A. Affandi \& B. Sarbeini, Penerj.). Jakarta: Pustaka Azzam, 2008.

Azhari, F. Qawaid Fighiyyah Muamalah. Banjarmasin: Lembaga Pengembangan Kualitas Umat, 2014.

Dahlan, A. A. Ensiklopedi Hukum Islam. Jakarta: Ikhtiar Baru van Hoeve, 1996.

Djamil, F. Filsafat Hukum Islam. Jakarta: Logos Wacana Ilmu, 1997.

Djazuli, A. Kaidah-Kaidah Fikih: Kaidah-Kaidah Hukum Islam dalam Masalah-Masalah yang Praktis. Jakarta: Kencana, 2006.

Girindra, A. Pengukir Sejarah Sertifikasi Halal. Jakarta: LPPOM-MUI, 1998.

Hamka. Tafsir al-Azhar (Vol. 7). Jakarta: Pustaka Panjimas, 1983.

Mufid, M. Ushul Figh Ekonomi dan Keuangan Kontemporer: Dari Teori Ke Aplikasi. Jakarta: Kencana, 2016.

Pelu, M. I. E. A. Label Halal: Antara Spiritualitas Bisnis dan Komoditas Agama. Malang: Madani, 2009.

Suryana. Makanan yang Halal dan Haram. Jakarta: Mitra Aksara Panaitan, 2009.

\section{Jurnal-jurnal}

Charity, M. L. (2017). Jaminan produk halal di Indonesia (Halal products guarantee in Indonesia). Jurnal Legislasi Indonesia, 14(1), 99-107.

Fila, S. Z. F. (2020). Kajian Teoritik Terhadap Urgensi Asas Dalam Akad (Kontrak) Syariah. Al - Muamalat: Jurnal Hukum Dan Ekonomi Syariah, 5(1), 48-67. https:/ / doi.org/10.32505/muamalat.v5i1.1519

Hasan, K. S. (2014). Kepastian Hukum Sertifikasi dan Labelisasi Halal Produk Pangan. Jurnal Dinamika Hukum, 14(2), 227-238.

Janah, T. N. (2020). Upaya Perlindungan Konsumen Muslim Dan NonMuslim Melalui Sertifikasi Halal Dan Transparansi Komposisi Produk Makanan. Islamic Review: Jurnal Riset dan Kajian Keislaman, 9(1), 65-85. https://doi.org/10.35878/islamicreview.v9i1.186 
Latif, M. A. (2020). Urgensi dan Eksistensi Undang-Undang Perlindungan Konsumen terhadap Praktik Bisnis. YUDISIA: Jurnal Pemikiran Hukum dan Hukum Islam, 11(1), 17-32. https://doi.org/10.21043/yudisia.v11i1.6390

Solihin, K. (2020). Analisis Kebijakan Sertifikasi Produk Halal Dalam Perspektif Perlindungan Kemaslahatan Umat. Islamic Review: Jurnal Riset dan Kajian Keislaman, 9(1), 1-37. https://doi.org/10.35878/islamicreview.v9i1.188

Syafrida, S. (2016). Sertifikat Halal Pada Produk Makanan Dan Minuman Memberi Perlindungan Dan Kepastian Hukum Hak-Hak Konsumen Muslim. ADIL: Jurnal Hukum, 7(2), 159-174.

Tamrin, D. (2010). Kaidah-kaidah Hukum Islam: Kulliyah al Khamsah. Malang: UIN Maliki Press.

VIVA, P. V. M. B.-. (2019, Oktober 16). Sertifikasi Halal Tak Lagi Wewenang MUI tapi Kementerian Agama. Diambil 14 Oktober 2020, dari https://www.viva.co.id/berita/nasional/1240361sertifikasi-halal-tak-lagi-wewenang-mui-tapi-kementerian-agama 
Muhammad Syarif Hidayatullah

Halaman ini sengaja dikosongkan 